\title{
INDICATORS OF SUSTAINABLE PEST MANAGEMENT IN ORCHARD PRODUCTION SYSTEMS
}

\author{
C.H. WEARING
}

\author{
HortResearch, Clyde Research Centre, RD1, Alexandra
}

\begin{abstract}
The achievement of sustainable orchard production is a process of continuous improvement in which unsustainable practices are progressively eliminated, while maintaining business profitability. Comparative studies of conventional and modified production systems provide a means to identify indicators of sustainability which are closely correlated with the improvements being made. Conventional, integrated, and biological apple production are being compared in three regions. Preliminary indicators of improved sustainability in pest management are: reductions in the use of broad-spectrum pesticides, increases in the numbers of mortality factors impacting on pest populations, greater diversity of arboreal predators and parasites, and higher populations of key natural enemies. Preliminary results are presented for the three systems, and the woolly apple aphid parasitoid, Aphelinus mali, is proposed as one of the key indicator species.
\end{abstract}

Keywords: Sustainability, pest management, apple production, biodiversity, biological control

\section{INTRODUCTION}

Sustainable agriculture has been defined as the use of practices and systems which maintain or enhance: the ability of people and communities to provide for their social and cultural well-being, the economic viability of agriculture, the natural resource base of agriculture, other ecosystems influenced by agricultural activities, and the quality and safety of food and fibre (MAF 1993). It follows that the sustainability of orchard production is complex, involving cultural, ecological, agricultural and economic components which are highly interactive. Moreover, these components and their interactions have different significance (and may require different measurements) at the farm, regional, national and global levels, and over different time intervals. Within the farm, the sustainability of a wide variety of production practices is being questioned, including soil, water, nutrient, pest, disease, and weed management.

Arising from this complexity, there is a plethora of indicators under study for "measuring" economic, agricultural and ecological sustainability. However, all address only a particular aspect of sustainability, they relate to different dimensions of time and space (farm to global), and they lack a common unit of measurement. For example, Liverman et al.(1988) discussed the use of "a physical quality of life index" and "energy imports as a percentage of consumption" for measuring global sustainability. At the farm level, Horne et al.(1994) discussed the use of soil indices and highlighted the difficulties of deriving measures of sustainability which reliably take balanced account of on-farm and downstream effects. It is reasonable to ask whether integrating these indicators into absolute measures of sustainability, within or between levels, is a useful proposition. A suite of indicators is often required at each level to monitor progress towards greater sustainability in the system under study. In the orchard, we need a series of practical indicators which relate closely to improvements being made in sustainable production practices. These indicators must have relevance to the fruitgrower, to the economic and ecological viability of the orchard, and to buyers and consumers who wish to purchase fruit grown using environmentally-sound production methods. Such indicators could then also be used to support eco-labelling and other marketing strategies.

The history of concern about the sustainability of fruit production is rooted in Proc. 50th N.Z. Plant Protection Conf. 1997: 506-513 
growing evidence that some aspects of conventional production are unsustainable for the orchard ecosystem and/or the wider environment. Unsustainable practices continue to be identified, and it is consumer responses to these which is driving market demand for more sustainable production. To balance the needs of economics and the environment, improvements are being achieved by incremental changes which focus on eliminating or reducing these unsustainable practices. Hence, the development of sustainable orchard production systems is a dynamic process of continuous improvement (e.g. Batchelor et al. 1997). In this scenario, the most practical measurement of the improved sustainability of production at the farm level is the extent to which it avoids practices which are considered unsustainable, at both the farm and global level, while maintaining the economic viability of the farm itself. Comparative studies of conventional and modified production systems, in which changes are made to unsustainable practices, provide a means to identify indicators of improvements in sustainability. Like the systems themselves, these indicators will need to change in relation to the particular practices being modified.

\section{Unsustainable practices}

The economic sustainability of an orchard business is essential, and lack of profitability is unsustainable. Table 1 summarises five other practices which have been identified as unsustainable in orchard production systems. This list is not exhaustive and has particular relevance to pest management. Environmental contamination beyond the farm is included (Table 1, a) because of the importance of pesticides in contributing to this problem. However, it is recognized that improvements in reducing contamination cannot be measured in-farm and would require regional or global indicators.

Pest resistance to unilateral pest control methods (Table 1, b) has been well documented for chemical pesticides and resistant plants, and has recently extended to include bacterial insecticides based onBacillus thuringiensisBerliner (Bt) (Wearing and Hokkanen 1995). Similar resistance problems are expected with transgenic crops containing single Bt genes (McGaughey and Whalon 1992). Pest management programmes which use a mix of control methods for each pest should be accompanied by fewer cases of resistance, and documentation of these cases provides a direct measure of the sustainability of pest management systems. Another comparative indicator in this context could be the numbers of control agents and methods used to maintain each pest population below economic damage levels in each production system, such as the numbers of parasitoid and predator species, plant resistance mechanisms, and physical and chemical control methods.

Conventional production systems have required the use of broad-spectrum chemicals toxic to many beneficial organisms, such as the natural enemies of pests. More sustainable systems should harness the benefits of these renewable resources (Table 1, e) without incurring associated economic loss, such as from the presence of the pest in the crop. For some pests, this can be achieved simply by removing chemicals toxic to the natural enemies themselves, while in other cases a combination of natural enemies and other selective control methods is required. Comparative indicators of improvements in sustainability between systems could be population data on the natural enemies, and/or particularkeystone species (Millset al. 1993), accompanied by (i) pest incidence below economic damage levels, and (ii) reduced pesticide use (see Table 1, a). Another approach to measuring greater use of renewable resources could be to compare the biodiversity of different production systems (Table 1, e; Suckling et al. 1997b), using greater biodiversity as an indicator of a more sustainable system. However, the relationship between overall biodiversity and sustainability is extremely complex and the assumption of a strong correlation is as yet unsubstantiated in orchard ecosystems. Orchards are not natural ecosystems and must provide an economic yield. Where the biodiversity measure focuses on predators and parasitoids contributing to pest management (Suckling et al. 1997a) (or to organisms with a known role in other ecosystem functions such as litter breakdown), this may provide a sounder basis for using biodiversity as an indicator of sustainability in orchards.

TABLE 1: Unsustainable orchard practices and potential indicators for comparing production systems. 
Practice

Possible in-farmindicators (comparative)

a. Use of fossil fuels and other non-renewable resources.

Quantities of products used from non-renewable sources e.g. synthetic pesticides based on the oil industry

b. Use of unilateral pest/disease/weed control methods leading to resistance e.g. to pesticides, to resistant plants, to transgenic plants.

c. Contamination of environment (beyond the farm) e.g. ground water.

No. of cases of resistance No. of mortality factors affecting pest populations - biological, chemical, and physical.

Not applicable.

Must be measured off-farm.

d. Destruction of soil structure and productivity through effects on See for example Horne et al. (1994) physical, chemical, and biological components.

e. Destruction of or failure to use renewable resources e.g. natural enemies of pests, antagonists of pathogens.

Natural enemy populations

Keystone predator/parasitoid species Biodiversity

\section{Production systems}

\section{METHODS}

Three pip-fruit production systems are being compared in replicated trials in three regions of New Zealand, Central Otago, Canterbury, and Hawkes Bay. The conventional fruit production (CFP) system includes the existing standard pest management programme for commercial orchards in the region. This is based mainly on schedules of organophosphate (OP) and carbamate (CB) insecticides, mite control with oil and miticide sprays and OPresistant predatory mites, a range of fungicide products, and a $2 \mathrm{~m}$ wide herbicide strip. Integrated fruit production (IFP) is the standard ENZA NZIFP-P(Batcheloret al. 1997, this volume) programme for the region which includes selective insect growth regulator(IGR) insecticides combined with very restricted use of $\mathrm{OP}$ and $\mathrm{CB}$, oils for scale control, mite control with predatory mites, and fungicides less disruptive to predatory mites than in CFP. Pesticides are used in IFP only when justified by pest monitoring and the herbicide strip is reduced to $1 \mathrm{~m}$. Biological fruit production (BFP) includes pest and disease management compatible with organic registration, and the Otago orchard has full BIO-GRO status. This includes mating disruption for codling moth control, spring oil for scale control, occasional use of Bt for leafroller control, and the restricted use of copper sprays plus sulphur, lime and/ or lime sulphur for disease management. Weed management in BFP uses matting, mulching, mowing, and cultivation. All three systems use disease and pest forecasting services to improve pesticide timing. At the Clyde Research Centre, three cultivars studied are common to the three production systems, 'Royal Gala', 'Braeburn', and 'Fuji'.

\section{Faunal sampling}

The use of beating trays and pit traps for faunal sampling in BFP, IFP and CFP, and the derivation of diversity indices for cultivar 'Fuji', were described by Suckling et al. (1997a and b). Further beating tray data and diversity indices are presented here for cv. 'Royal Gala' at Clyde. In addition, in the three systems at the Clyde site, pests and their natural enemies were monitored by shoot sampling, sticky traps, pheromone traps, colony sampling (woolly apple aphid, (Eriosoma lanigerum), and leaf sampling and brushing (mites and their predators). At harvest, a minimum of 1200 fruits from 12 trees per cultivar were examined for damage and infestation by all insect and mite pests. These sampling systems provided data on the numbers of natural enemy species attacking each pest and on the population density of some species in relation to crop damage. 


\section{Numbers of mortality factors}

\section{RESULTS}

The only documented case of resistance in Central Otago apple pests is in greenheaded leafroller (Planotortrix octo) (Wearing 1995) although OP miticides ceased to be effective against tetranychids before the arrival of OP-resistant predatory mites. Both these resistances arose during heavy dependence on unilateral chemical control.

TABLE 2: Numbers of mortality factors affecting populations of major apple pests in three orchard production systems on three cultivars at Clyde, Central Otago.

\begin{tabular}{|c|c|c|c|}
\hline $\begin{array}{l}\text { Pest species } \\
\text { or group }\end{array}$ & CFP & IFP & BFP \\
\hline Leafrollers & $\begin{array}{l}\text { OP/CB sprays } \\
\text { Nat. enemies }=0\end{array}$ & $\begin{array}{l}\text { IGR sprays } \\
\text { Nat. enemies }=3 *\end{array}$ & $\begin{array}{l}\text { Bt sprays } \\
\text { Nat. enemies }=5+3 *\end{array}$ \\
\hline $\begin{array}{l}\text { Codling moth } \\
\text { (Cydia pomonella) }\end{array}$ & $\begin{array}{l}\text { OP/CB sprays } \\
\text { Nat. enemies }=0\end{array}$ & $\begin{array}{l}\text { IGR sprays } \\
\text { Removal of } \\
\text { sources of } \\
\text { immigration } \\
\text { Nat. enemies }=3 *\end{array}$ & $\begin{array}{l}\text { Mating disruption } \\
\text { Granulosis virus } \\
\text { sprays } \\
\text { Bt sprays } \\
\text { Removal of } \\
\text { sources of } \\
\text { immigration } \\
\text { Nat enemies }=1+3 *\end{array}$ \\
\hline $\begin{array}{l}\text { Woolly apple } \\
\text { aphid (WAA) }\end{array}$ & $\begin{array}{l}\text { OP sprays } \\
\text { Nat. enemies =0 } \\
\text { Resistant } \\
\text { rootstocks }\end{array}$ & $\begin{array}{l}\text { Nat. enemies = } 4 \\
\text { Resistant } \\
\text { rootstocks }\end{array}$ & $\begin{array}{l}\text { Nat. enemies = } 4 \\
\text { Resistant } \\
\text { rootstocks }\end{array}$ \\
\hline Scales insects & $\begin{array}{l}\text { OP sprays } \\
\text { Mineral oil } \\
\text { Nat. enemies =0 }\end{array}$ & $\begin{array}{l}\text { IGR sprays } \\
\text { Mineral oil } \\
\text { Nat. enemies = } 2 \\
\text { Resistant shelter } \\
\text { trees }\end{array}$ & $\begin{array}{l}\text { Mineral oil } \\
\text { Nat. enemies = } 2 \\
\text { Resistant shelter } \\
\text { trees }\end{array}$ \\
\hline $\begin{array}{l}\text { Twospotted } \\
\text { spider mite (TSM, } \\
\text { Tetranychus } \\
\text { urticae) }\end{array}$ & $\begin{array}{l}\text { Tin miticide sprays } \\
\text { Mineral oil } \\
\text { Nat. enemies }=2\end{array}$ & Nat. enemies $=6$ & Nat. enemies $=7$ \\
\hline $\begin{array}{l}\text { European red } \\
\text { mite (ERM, } \\
\text { Panonychus ulmi) }\end{array}$ & $\begin{array}{l}\text { Tin miticide sprays } \\
\text { Mineral oil } \\
\text { Nat. enemies }=2\end{array}$ & Nat enemies $=6$ & Nat. enemies $=7$ \\
\hline
\end{tabular}

* The predatory bugs Orius vicinus and Sejanus albisignata, and the predatory mite Anystis baccarum, are common and known to feed on eggs and young larvae, but predation has not been observed in the field at Clyde.

Except for mite control, CFP remains highly dependent on few control methods whereas pests in both IFP and BFP are subject to a wider range of mortality factors (Table 2). OP insecticides are permitted in IFP but have been used at Clyde only experimentally on an IFP 'Royal Gala' block. When diazinon was applied to half of this block (6.12.96) for control of apple leafcurling midge (Dasineura mali), natural enemy populations in 
the sprayed area were largely eliminated (see below) and, until recolonisation, few mortality factors were operating on the pest populations.

Use of renewable resources - natural enemies

The benefits of additional natural enemies for some pests in IFP and BFP (Table 2) were confirmed by analysis of WAA and mite management results at Clyde (Table 3).

TABLE 3: Major biological and chemical controls acting on WAA, ERM and TSM in relation to infestation at harvest in three production systems.

\begin{tabular}{llcl}
\hline $\begin{array}{l}\text { Season, pest, } \\
\text { and system }\end{array}$ & $\begin{array}{c}\text { Parasitism }(\%)^{*} \\
\text { or peak predator:prey } \\
\text { ratio(nos/leaf)** }\end{array}$ & $\begin{array}{c}\text { No. of chemical } \\
\text { sprays applied }\end{array}$ & $\begin{array}{c}\text { Infestation at } \\
\text { harvest (\%) }\end{array}$ \\
\hline
\end{tabular}

\begin{tabular}{rlllc}
\hline 1996 & & & & \\
WAA & - CFP & $0(\mathrm{n}=10)$ & 4 & $0.03 \pm 0.03$ \\
& - IFP & $8.5 \pm 4.8(\mathrm{n}=59)$ & 0 & $0.47 \pm 0.33$ \\
- BFP & $100.0(\mathrm{n}=11)$ & 0 & $0.007 \pm 0.007$ \\
ERM+ - CFP & $0.12: 0.02$ & 1 & 0 \\
- IFP & $0.40: 0.96$ & 0 & 0 \\
- BFP & $0.27: 0.51$ & 0 & $0.26 \pm 0.19$ \\
TSM+ - CFP & $0.12: 0.96$ & 1 & 0 \\
- IFP & $0.40: 5.80$ & 0 & $0.40 \pm 0.24$ \\
- BFP & $0.27: 0.93$ & 0 & $0.10 \pm 0.04$
\end{tabular}

1997

\begin{tabular}{|c|c|c|c|c|}
\hline \multirow[t]{3}{*}{ WAA } & - CFP & $0(n=2)$ & 4 & 0 \\
\hline & - IFP & $65.6 \pm 12.5(n=35)$ & 0 & $0.06 \pm 0.04$ \\
\hline & - BFP & $-* * *$ & 0 & 0 \\
\hline \multirow[t]{3}{*}{ ERM+ } & - CFP & 0.29:0.00 & 0 & 0 \\
\hline & - IFP & $1.07: 0.00$ & 0 & 0 \\
\hline & - BFP & $0.02: 0.65$ & 0 & 0 \\
\hline \multirow[t]{3}{*}{ TSM+ } & - CFP & $0.29: 0.23$ & 0 & $1.99 \pm 0.90$ \\
\hline & - IFP & 1.07:0.70 & 0 & $1.00 \pm 0.63$ \\
\hline & - BFP & $0.02: 0.52$ & 0 & $0.10 \pm 0.06$ \\
\hline
\end{tabular}

* percentage of colonies parasitised by $A$. mali.

** Ratio of peak numbers of active stages of phytoseiid mites to ERM or TSM.

$* * *$ No colonies could be found.

+ Fuji data only, see text.

The IFP programme was in its second season in 1996 (ex-CFP) whereas the BFP orchard had been operating for 4 years since planting. Harvested fruit in BFP were as free of WAA as the CFP trees due to, respectively, $100 \%$ parasitism of colonies and the insecticide programme. This continued in 1997 and rising parasitism in the IFP population resulted in non-economic levels of WAA in the fruit at harvest.

Mite infestation of the fruit at harvest was non-economic on all cultivars except 'Fuji' (Table 3), and then only in 1997. No miticide was applied to CFP trees in that season and predator populations did not increase in either CFP or IFP until the end of March. This was too late to prevent small numbers of TSM from moving onto the fruit. Mite management in IFP and BFP was assisted by a range of natural enemies in addition to phytoseiids.

\section{Use of renewable resources - biodiversity}

The diversity of arboreal fauna obtained from cv. 'Royal Gala' into beating trays was consistently lower in CFP than in IFP or BFP(Fig. 1A \& see Sucklinget al. 1997b)). High diversity was obtained in BFP throughout the season but it increased from initial lower levels in IFP and CFP. As a result, faunal diversity in IFP and BFP were similar from late 
January. The diversity of natural enemies in the three systems showed trends similar to the total fauna, except that it remained very low in CFP all season and there was some decline in BFP(Fig 1B). This may have been in response to regular sprays of sulphur and some copper applications. For example, apple rust mite (Aculus schlechtendali) populations were greatly reduced by these sprays and this was associated with similar reductions in populations of the predatory bug, $O$. vicinus, compared to previous seasons. IFP and BFP had similar levels of diversity of natural enemies through the season. These and the results of Suckling et al. (1997) indicate that biodiversity under IFP without OP sprays is at least equal to that in BFP, which at Clyde Research Centre is a BIO-GRO registered orchard.

Application of diazinon in early December to half of an IFP 'Royal Gala' block reduced faunal diversity but this recovered rapidly (Fig. 1C). In contrast, the reduction in diversity of natural enemies persisted to the end of the season (Fig. 1D).

\section{DISCUSSION}

The only means of measuring fully the ecological sustainability of total production systems is life cycle analysis (LCA), in which their contribution to regional and global pollution is assessed at every stage from planting to market. This parallels the application of LCA to assessment of chemical pollutants (van Emden and Peakall 1996). LCA
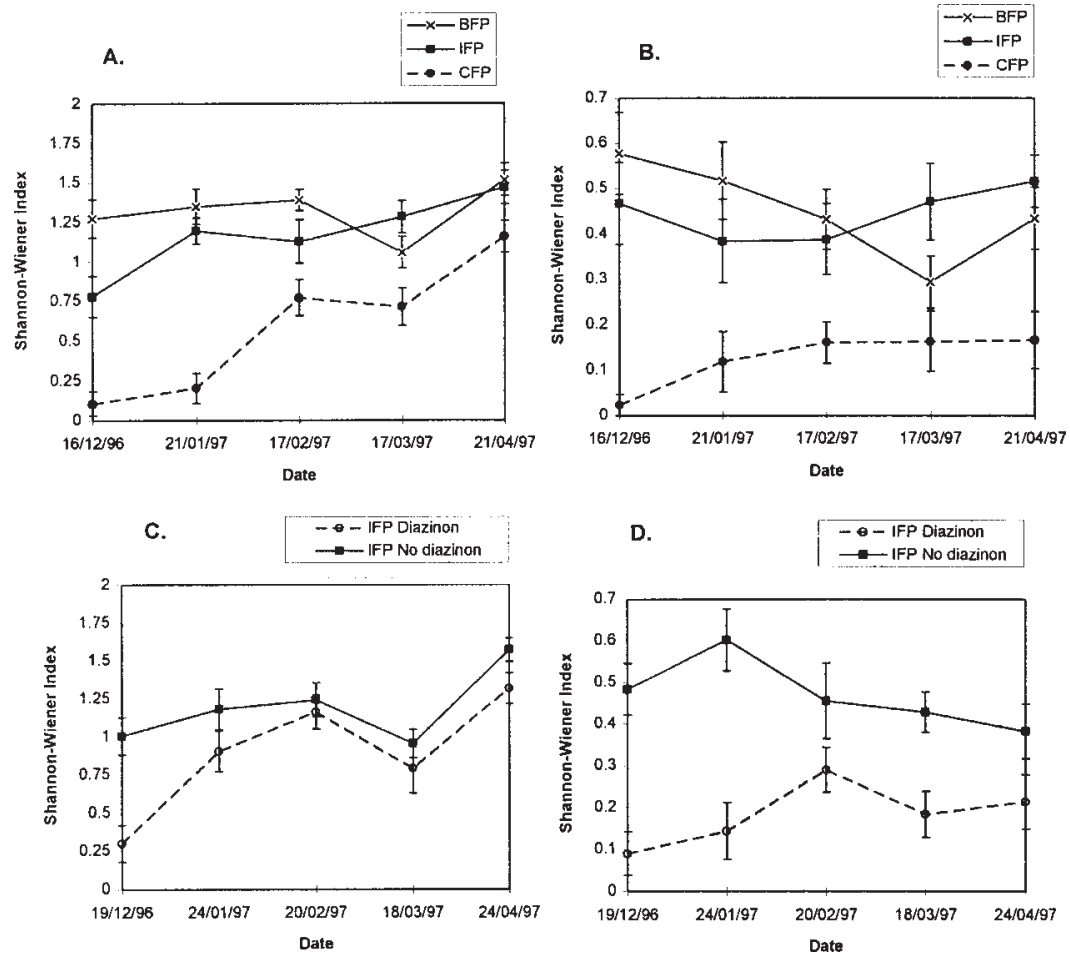

D.

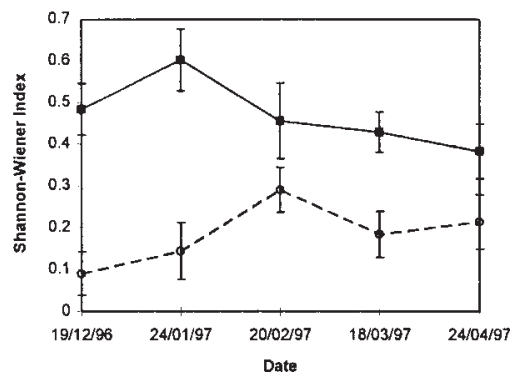

FIGURE 1: Shannon-Wiener diversity indices for the total arboreal fauna (A and $C$ ) and natural enemies ( $B$ and $D$ ) obtained in beating trays used in cv. 'Royal Gala' trees grown under BFP, IFP, CFP or IFP with diazinon. Separate blocks of trees were used for the data in $A, B$ and C, D. 
research has begun into CFP, IFP, and BFP(L. Hemensen pers. comm.) and this process may reveal further orchard management practices which are unsustainable because of their contribution to regional and global problems (Table 2); agricultural research has identified practices which cannot be sustained within the farm (e.g. pesticide resistance, uneconomic practices). By comparing the three apple production systems, the following preliminary indicators of more sustainable pest management have been identified to date:

(i) reductions in pesticide use (especially broad-spectrum chemicals)and

(ii) increases in the numbers of mortality factors impacting on pest populations and

(iii) higher populations of key natural enemies and/or

(iv) greater diversity of the arboreal natural enemy fauna

To be valid indicators of improved sustainability, the profitability of the business must be maintained during these changes, including

(v) acceptable levels of crop damage.

The present studies have also shown that:

(vi) the WAA parasitoid, A. mali, could be used as a key indicator species for the improvements being sought at this time.

Reductions in pesticide use can be monitored by the Pesticide Rating System which is under development (Walker et al. 1997); this has the added advantage of monitoring environmental and other impacts of pesticides within its points system.

The results to date from the present study indicate that major improvements in this (Walker et al. 1997) and other aspects of sustainable pest management can be achieved with IFP or BFP. A full discussion of the economics of CFP, IFP and BFP is beyond the scope of this paper. However, the IFP programme has been tested on a number of commercial orchards in Otago (and in other regions) in 1996-97 and the preliminary results indicate that profitability has been maintained or increased. In addition, apples of cvs 'Fuji' and 'Royal Gala' grown under BFP at Clyde were exported to Europe in 1997 and the percentages of export packout were similar to conventional fruit from the region. This BFP fruit, which has been produced with BIO-GRO certification, commanded a premium and an analysis of the economics of BFP for the region is in progress.

\section{ACKNOWLEDGEMENTS}

I thank my colleagues D.M. Suckling, G.F. McLaren, M.J. Daly, G.M. Burnip, A.R. Gibb, and T. McCarthy for discussions on sustainability. The technical assistance of B. Attfield and K. Colhoun is gratefully acknowledged.

\section{REFERENCES}

Batchelor, T.A., Walker, J.T.S., Manktelow, D.W.L., Park, N.M. and Johnson, S.R., 1997. New Zealand integrated fruit production for pipfruit - charting a new course. Proc. 50th N.Z. Plant Prot. Conf.: (this volume).

Horne, D.J., Palmer, A.S., MacGregor, A.N. and Horne, M.L., 1994. Some problems in identifying and using soil indices to measure sustainability.Proc. 1994 N.Z. Conf. Sustain. Land Management: 173-179.

Liverman, D.M., Hanson, M.E., Brown, B.J. and Merideth, R.W. Jr, 1988. Global sustainability: Toward measurement. Environ. Management 12: 133-143.

McGaughey, W.H. and Whalon, M. E., 1992. Managing insect resistance to Bacillus thuringiensis toxins. Science 258: 1451-1455.

MAF, 1993. Sustainable agriculture. MAF Policy Position Paper 1: 32 pp.

Mills, L.S., Soulé, M.E. and Doak, D.F., 1993. The keystone species concept in ecology and conservation. Bio-Science 43: 219-214.

Suckling, D.M., Walker, J.T.S. and Wearing, C.H., 1997a. Ecological impact of three pest management systems in New Zealand apple orchards. Agric. Ecos. Env. (in press)

Suckling, D.M., Wearing, C.H., Gibb, A.R., Burnip, G.M., Attfield, B. and Colhoun, K., 1997b. Biodiversity in apple orchards: Apple tree foliage and ground cover sampling. Proc.50th N.Z. Plant Prot. Conf.: (this volume).

van Emden, H.F. and Peakall, D.B., 1996. Beyond Silent Spring. Integrated Pest 
Management and Chemical Safety. Chapman and Hall, London. 322 pp.

Walker, J.T.S., Hodson, A.J., Batchelor, T.A., Manktelow, D.W. and Tomkins, A.R., 1997. A pesticide rating system for monitoring agrichemical inputs in New Zealand horticulture. Proc. 50th N.Z. Plant Prot. Conf.: (this volume).

Wearing, C.H., 1995. Resistance of Planotortrix octo to organophosphate insecticides in Dumbarton, Central Otago. Proc. 48th N.Z. Plant Prot. Conf.: 40-45.

Wearing, C.H. and Hokkanen, H.M.T., 1995. Pest resistance toBacillus thuringiensis: Ecological crop assessment for Bt gene incorporation and management strategies. Chapter 23.Pp. 236-252In:Biological Control:Benefits and Risks, H.M.T.Hokkanen and J.M. Lynch (Eds) Cambridge University Press, U.K. 